\title{
Cutinase activity in supercritical and organic media: water activity, solvation and acid-base effects
}

\author{
Sílvia Garcia ${ }^{\mathrm{a}}$, Pedro Vidinha ${ }^{\mathrm{a}}$, Helena Arvana ${ }^{\mathrm{a}}$, Marco D.R. Gomes da Silva ${ }^{\mathrm{a}}$, \\ M. Olga Ferreira ${ }^{c}$, Joaquim M.S. Cabral ${ }^{b}$, Eugénia A. Macedo ${ }^{c}$, \\ Neil Harper ${ }^{\mathrm{a}}$, Susana Barreiros ${ }^{\mathrm{a}, *}$ \\ ${ }^{a}$ REQUIMTE/CQFB, Departamento de Química, FCT, Universidade Nova de Lisboa, 2829-516 Caparica, Portugal \\ ${ }^{\mathrm{b}}$ Centro de Engenharia Biológica e Química, Instituto Superior Técnico, 1049-001 Lisboa, Portugal

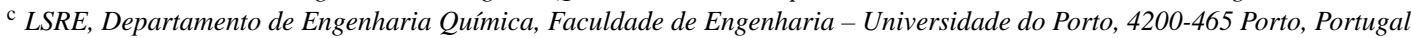

Received 7 April 2004; received in revised form 1 October 2004; accepted 13 October 2004

\begin{abstract}
We performed a comparative study on the activity of Fusarium solani pisi cutinase immobilized on zeolites NaA and NaY, in $n$-hexane, acetonitrile, supercritical ethane (sc-ethane) and $\mathrm{sc}-\mathrm{CO}_{2}$, at two different water activity $\left(a_{\mathrm{W}}\right)$ values set by salt hydrate pairs in situ and at acid-base conditions fixed with solid-state buffers of aqueous $\mathrm{p} K_{\mathrm{a}}$ between 4.3 and 10.6. The reaction studied was the transesterification of vinyl butyrate by $(R, S)$-2-phenyl-1-propanol. The transesterification activity of cutinase was highest and similar in sc-ethane and in $n$-hexane, about one order of magnitude lower in acetonitrile and even lower in $\mathrm{sc}-\mathrm{CO}_{2}$. Activity coefficients $(\gamma)$ generated for the two substrates indicated that they were better solvated in acetonitrile and thus less available for binding at the active site than in the other three solvents. $\gamma$ data also suggested higher reaction rates in sc-ethane than in $n$-hexane, as observed, and provided evidence for a direct negative effect of sc- $\mathrm{CO}_{2}$ on enzyme activity. Manipulation of the acid-base conditions of the media did not afford any improvement of the initial rates of transesterification relative to the blanks (no added acid-base buffer, only salt hydrate pair), except in the case of cutinase immobilized on zeolite $\mathrm{NaA}$ in sc-ethane at $a_{\mathrm{W}}=0.7$. The poor performance of the blank in this case and the great improvement observed in the presence of a basic buffer suggest a deleterious acidic effect in the medium which, an experiment without additives confirmed, was not due to the known acidic character of the salt hydrate pair used to set $a_{\mathrm{W}}=0.7$. In acetonitrile, increasing $a_{\mathrm{W}}$ was accompanied by a decrease in initial rates of transesterification, unlike in the other solvents. There was considerable hydrolysis in acetonitrile, where initial rates of hydrolysis increased about 20-fold from $a_{\mathrm{W}}=0.2$ to 0.7 . Hydrolysis was less pronounced in sc-ethane and in $n$-hexane, and only at $a_{\mathrm{W}}=0.7$, and in sc-CO $\mathrm{CO}_{2}$ butyric acid was detected only at very long reaction times, in agreement with a generally low catalytic activity. Cutinase enantio-selectivity towards the alcohol substrate was low and unaffected by any manipulation of medium conditions.
\end{abstract}

(C) 2004 Elsevier B.V. All rights reserved.

Keywords: Cutinase; Enzyme protonation state; Activity coefficients; Zeolites; Supercritical fluids; Organic solvents

\section{Introduction}

Environmental concerns are an important driving force towards green chemistry today and the use of supercritical fluids (sc-fluids) is a good strategy to meet those concerns [1,2]. One of the areas where the use of sc-fluids holds promise is that of biocatalysis [3]. It is now firmly established that

\footnotetext{
* Corresponding author. Tel.: +35121 2949681; fax: +351212948385.

E-mail address: sfb@dq.fct.unl.pt (S. Barreiros).
}

in nonaqueous media enzymes are able to catalyze reactions that are difficult or impossible to carry out in water, become more stable and can exhibit altered selectivity [4], and some applications of nonaqueous enzymology are already commercialized [4,5]. In these media, the preservation of enzyme function is due to the fact that the enzyme essentially retains its native structure, as revealed by X-ray studies [6-8]. The limited availability of water ensures that the enzyme remains kinetically trapped in its native conformation [9]. Water acts as a molecular lubricant and although a certain level of hy- 
dration must be reached before the enzyme has the dynamics required for catalytic activity [10,11], increasing hydration may allow the enzyme to overcome the energy barrier that will lead to denaturation.

Water activity $\left(a_{\mathrm{W}}\right)$ is the most convenient parameter for correlating enzymatic activity in nonaqueous media $[12,13]$. At fixed $a_{\mathrm{W}}$, solvent effects due to differences in water partitioning are mostly eliminated, leading to the same level of enzyme hydration in all the solvents (more polar media, which at high $a_{\mathrm{W}}$ values can compete with less tightly bound water, may lead to comparatively lower levels of enzyme hydration at high $\left.a_{\mathrm{W}}\right)[14,15]$. When considering a transesterification reaction, and in the case of hydrolases such as cutinase which act via the acyl-enzyme mechanism, increasing $a_{\mathrm{W}}$ affects the competition for the nucleophile in the deacylation step, which in many cases will bring about an increase in the initial rates of formation of the acid by-product via hydrolysis of the ester substrate. As for rates of transesterification, there is usually a range of $a_{\mathrm{W}}$ values that lead to a maximum, although factors such as enzyme immobilization and the nature of the support may have a marked effect on the rate versus $a_{\mathrm{W}}$ profile observed [16,17]. At very low $a_{\mathrm{W}}$ values, an increase in $a_{\mathrm{W}}$ is expected to enhance enzyme activity via an increase in enzyme dynamics [18-20]. At high $a_{\mathrm{W}}$ values, phenomena such as particle aggregation may occur as well as a decrease in the rate of uptake of the substrates through the hydration layer of the catalyst [21] that can negatively impact on initial rates of transesterification.

The solvation of the substrates (or products) will likely differ from solvent to solvent and this will be reflected on enzyme activity [22-25]. The better the solvent solvates the substrate molecules, the less favorable desolvation into the active site will be [26]. This will result in larger $K_{\mathrm{m}}$ values (where $K_{\mathrm{m}}$ is the Michaelis-Menten constant for dissociation) and will have a negative impact on catalytic activity [14]. As with water, analysis of the availability of the substrates requires consideration of substrate activities [13]. The effect of $a_{\mathrm{W}}$ on the solvation ability of the solvent should be taken into account in cases where changes in $a_{\mathrm{W}}$ are accompanied by a considerable change in water concentration [14], such as with acetonitrile, and should not be relevant in water-immiscible solvents that become saturated at infinite dilution concentrations of water, such as $n$-hexane, sc-ethane or sc- $\mathrm{CO}_{2}$.

The solvent may also affect the catalytic activity of the enzyme via direct molecular solvent/enzyme interactions, e.g. the binding of solvent molecules directly at the enzyme active site has been evidenced by X-ray studies $[6,7,27]$. This can cause changes in polarity and impact on the stabilization of charged transition states [26], as involved in the catalytic mechanism of serine hydrolases such as cutinase that require the establishment of a formal negative charge on the active site for full activity. Binding of solvent molecules at the active site can also result in competitive inhibition with the substrates [23]. Apparently, there have been no reports on adverse direct effects of $n$-hexane (or sc-ethane) on enzyme activity, unlike in acetonitrile [14] and in sc- $\mathrm{CO}_{2}$. Explanations put forward for the deleterious effect of $\mathrm{CO}_{2}$ include the generation of carbonic acid in the hydration layer of the enzyme, which is very difficult to overcome even at very low $a_{\mathrm{W}}$ values [28], and the formation of carbamates on free amine groups of lysine residues, more relevant at low $a_{\mathrm{W}}$ and high basicity [29].

The protonation state of the enzyme is another factor that can have a marked effect on catalytic activity [30]. Enzyme immobilization onto a support usually involves an aqueous buffered solution at an optimum $\mathrm{pH}$. In this case, subsequent removal of water through the vapor phase leaves the protonation state of the protein residues unaltered, and the enzyme molecules will exhibit "pH memory", thus "remembering" the $\mathrm{pH}$ of the last aqueous solution contacted [31,32]. However, in the presence of ion-exchangers or of acidic or basic species, changes in the protonation state of the enzyme may occur. These changes may prevent the observation of true $a_{\mathrm{W}}$ effects on catalytic activity, e.g. a diminished catalytic activity at high $a_{\mathrm{W}}$ may simply reflect the production of an acidic by-product in the reaction medium, the elimination of which with an appropriate buffer would make visible the activation of the enzyme at high $a_{\mathrm{W}}$ [33]. Solid-state buffers have been described that control the ionization state of the enzyme in the nonaqueous phase by exchanging protons and ions closely associated with ionizable groups on the protein [34-36].

Here we address the impact of most of the effects described above on the activity of cutinase immobilized on zeolites $\mathrm{NaA}$ and $\mathrm{NaY}$ in $n$-hexane, acetonitrile, sc-ethane and sc- $\mathrm{CO}_{2}$, in the transesterification of vinyl butyrate by $(R, S)$-2-phenyl-1propanol.

\section{Materials and methods}

\subsection{Materials}

Fusarium solani pisi cutinase was produced by an Escherichia coli WK-6 (a gift from Corvas International, Ghent, Belgium) and purified at Centro de Engenharia Biológica e Química, Instituto Superior Técnico [37,38]. The enzyme purity was controlled by electrophoresis and isoelectric focusing. The estereolytic activity of the enzyme $(30 \mathrm{nM})$ was determined spectrophotometrically by following the hydrolysis of $p$-nitrophenyl butyrate $(0.56 \mathrm{mM})$ at $400 \mathrm{~nm}$ in a $50 \mathrm{mM}$ potassium phosphate buffer at $\mathrm{pH}=8.5$.

$(R, S)$-2-Phenyl-1-propanol (97\% purity), zeolite NaA and zeolite $\mathrm{NaY}$ molecular sieves, both in powder form, were from Aldrich; vinyl butyrate (99\% purity) was from Fluka; tridecane, 3-(cyclohexylamino)-2-hydroxy-1propanesulfonic acid (CAPSO), 3-( $N$-morpholino) propanesulfonic acid (MOPS), L-glutamic acid (GLU) and their sodium salts (CAPSO-Na, AMPSO-Na, MOPS·Na, GLU.Na) were from Sigma; $n$-hexane, acetonitrile, disodium hydrogen phosphate, di-sodium hydrogen phos- 
phate dihydrate, di-sodium hydrogen phosphate heptahydrate, sodium carbonate, sodium bicarbonate and sodium chloride were from Merck; potassium acetate and Hydranal Coulomat A and C Karl-Fischer reagents were from Riedel de Häen. ( $R, S)$-2-Phenyl-1-propyl butyrate was prepared as described [17]. The organic solvents, substrates and tridecane were stored over molecular sieves ( $3 \AA$ beads from Merck). Ethane, $\mathrm{CO}_{2}$, and nitrogen were supplied by Air Liquide and guaranteed to have purities of over $99.95 \mathrm{~mol} \%$ (ethane) and $99.995 \mathrm{~mol} \%$.

\subsection{Enzyme immobilization}

Cutinase was immobilized by deposition, according to the method developed by Gonçalves et al. [39] and Serralha et al. [40]. The lyophilized enzyme was dissolved in a $50 \mathrm{mM}$ sodium phosphate buffer solution ( $10 \mathrm{mg} \mathrm{mL}^{-1}$ of enzyme) at $\mathrm{pH}$ 8.5. The support was added to the solution $(25 \mathrm{mg}$ of cutinase per $\mathrm{g}$ of support) and after vortex mixing for $1 \mathrm{~min}$, the preparation was dried under vacuum for at least $24 \mathrm{~h}$. The average yield of immobilization was $(51 \pm 8) \%$ for zeolite $\mathrm{NaA}$ and $(72 \pm 12) \%$ for zeolite $\mathrm{NaY}$, as determined by a modified Lowry method [41].

\subsection{Enzyme assays}

For reactions in sc-fluids, we used variable-volume stainless steel cells (reaction mixture volume of about $12 \mathrm{~cm}^{3}$ ) equipped with a sapphire window and with loading and sampling valves. Details of the high-pressure apparatus and experimental technique have been given elsewhere [42]. Reactions in organic solvents were performed in screw-capped polypropylene vials $\left(3.5 \mathrm{~cm}^{3}\right.$ reaction volume). The salt hydrate pairs used $\left(42 \mathrm{~g} \mathrm{~L}^{-1}\right.$ of each form) and $a_{\mathrm{W}}$ values they set at $35^{\circ} \mathrm{C}[43]$ were: $\mathrm{Na}_{2} \mathrm{HPO}_{4} \cdot 2 / 0\left(a_{\mathrm{W}}=0.19\right)$, $\mathrm{Na}_{2} \mathrm{HPO}_{4} \cdot 7 / 2\left(a_{\mathrm{W}}=0.69\right)$. In the case of acetonitrile, $a_{\mathrm{W}}$ was adjusted prior to addition of the salt hydrate pairs (the amount of water required was derived from the data given by Bell et al. [14]). Solid-state acid-base buffers were used at $11 \mathrm{~g} \mathrm{~L}^{-1}$ (basic form) and $3 \mathrm{~g} \mathrm{~L}^{-1}$ (acidic form). The reaction studied was the transesterification of vinyl butyrate $(170 \mathrm{mM})$ by $(R, S)-2$-phenyl-1-propanol $(25 \mathrm{mM})$. The enzyme preparations were always allowed to equilibrate with any solid components present in the bulk nonaqueous phase (solvent, $(R, S)$-2-phenyl-1-propanol and tridecane) for $2 \mathrm{~h}$ to allow ample time for water and ionic transfer, before adding vinyl butyrate to start the reaction. Tridecane $(27 \mathrm{mM})$ was used as internal standard for GC analysis. Reaction mixtures were stirred with a stirring bar. Water concentration was measured in all the solvents by Karl-Fischer titration. In sc-fluids, $a_{\mathrm{W}}$ values were calculated by dividing the water concentration in the reaction mixture by the water concentration in the same mixture at saturation [44]. Unlike in organic solvents, reactions in sc-fluids are conducted in closed circuit. This may explain the interference of acetaldehyde (resulting from vinyl alcohol) in the Karl-Fischer measurements in the course of reaction, which were abandoned. To reach $a_{\mathrm{W}}=0.7$ in sc-ethane in experiments without acid-base buffers or salt hydrate pairs, the required amount of water was added to scethane in a chamber prior to admission into the reactor with enzyme, to avoid hydration hysteresis effects [45] and/or aggregation. In all cases, the enzyme was pre-equilibrated for about 3 days through the vapor phase with saturated salt solutions at $25^{\circ} \mathrm{C}$, to achieve the values $a_{\mathrm{W}}=0.22$ (potassium acetate) and $a_{\mathrm{W}}=0.75$ (sodium chloride), taken from the literature [46].

\subsection{Analysis}

Both reaction conversion and the enantiomeric excess of the remaining alcohol substrate (e.e.s) were measured by GC analysis performed with a Trace 2000 Series Unicam gas chromatograph. Column: $30 \mathrm{~m} \times 0.32 \mathrm{~mm}$ i.d. home-made fused silica capillary column coated with a $0.25 \mu \mathrm{m}$ thickness film of $15 \%$ heptakis-(2,3-di- $O$-methyl-6$O$-tert-butyldimethylsilyl)- $\beta$-cyclodextrin in SE 52 (DiMe). Oven temperature program: $90^{\circ} \mathrm{C}$ for $5 \mathrm{~min}, 90-136^{\circ} \mathrm{C}$ ramp at $0.8^{\circ} \mathrm{C} \mathrm{min}^{-1}, 200^{\circ} \mathrm{C}$ for $5 \mathrm{~min}$. Injection temperature: $250^{\circ} \mathrm{C}$. Flame ionization detection (FID) temperature: $250^{\circ} \mathrm{C}$. Carrier gas: helium $\left(2.0 \mathrm{~cm}^{3} \mathrm{~min}^{-1}\right)$. Split ratio: 1:20. No products were detected in assays carried out without enzyme. The enantiomeric ratio, $E$, was calculated from the expression $E=\{\ln [(1-c)(1-$ e.e.s $)]\} /\{\ln [(1-c)(1+$ e.e.s $)]\}$, where $c$ is the conversion [47] and e.e.s is given for the $(R)$ enantiomer, by using data obtained for the racemic substrate along the time course of the reaction (when possible, up to a conversion of 0.5 ).

\subsection{Activity coefficients}

The activity coefficients in the symmetric convention, $\gamma$ ( $\gamma=a / x$, where $a$ is the activity and $x$ the mole fraction) for the substrates in organic solvents were calculated using the modified UNIFAC group contribution method of Lingby [48], whereas $\gamma$ values for the substrates in sc-fluids were calculated using the MHV2 (modified Huron-Vidal second-order mixing rule) group contribution equation of state [49,50]. Neither enzyme nor additives were taken into account in these calculations.

\section{Results and discussion}

Initial rates of transesterification of vinyl butyrate by $(R, S)$-2-phenyl-1-propanol were similar in sc-ethane and in $n$-hexane and considerably higher than in acetonitrile and in sc- $\mathrm{CO}_{2}$ under all the conditions tested (Figs. 1 and 2). In addition to controlling $a_{\mathrm{W}}$ in all the experiments, we also ensured control of the protonation state of the acidic groups on the enzyme, by using acid-base buffers that fix the parameter $\mathrm{pH}-\mathrm{pNa}$ [30]. The exceptions were the blanks (no acid-base buffer, only salt hydrate pairs). Nonetheless, 


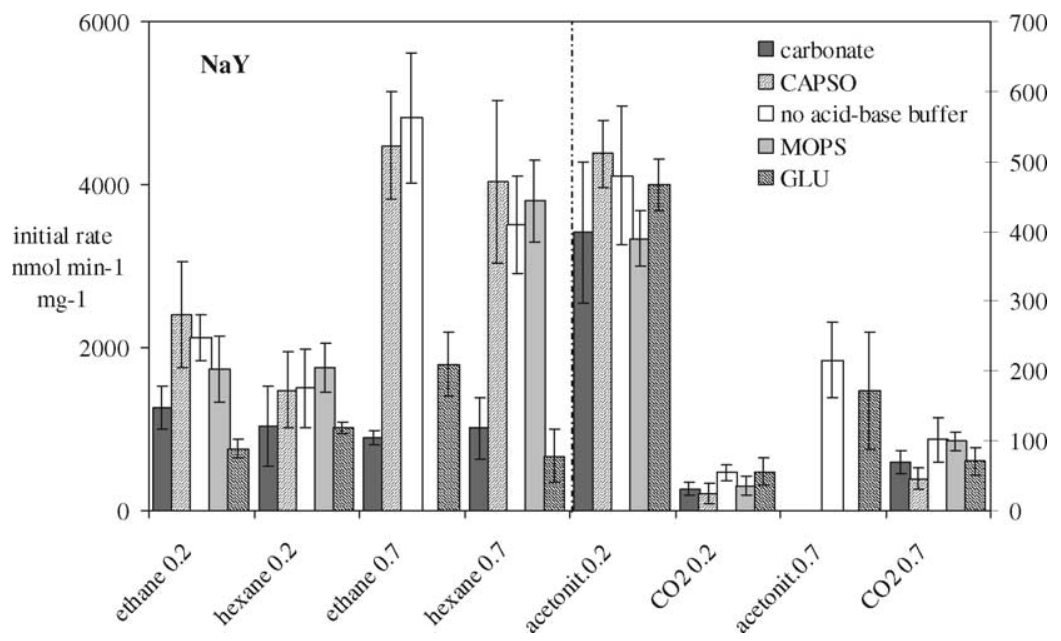

Fig. 1. Effect of solid-state acid-base buffer and $a_{\mathrm{W}}$ on the initial rates of transesterification for cutinase immobilized on zeolite NaY in sc-fluids and organic solvents. Left $y$-axis used for sc-ethane and $n$-hexane (data to the left of the dashed line). Buffer aqueous $\mathrm{p}_{\mathrm{a}}\left(\right.$ at $\left.25^{\circ} \mathrm{C}\right): 10.3\left(\mathrm{Na}_{2} \mathrm{CO}_{3} / \mathrm{NaHCO}_{3}\right)$, 9.6 (CAPSO/CAPSO-Na), 7.2 (MOPS/MOPS.Na), 4.3 (GLU/GLU.Na). $T=35^{\circ} \mathrm{C} . P=100$ bar (sc-fluids). [2-phenyl-1-propanol] $=25 \mathrm{mM}$. [vinyl butyrate] $=170 \mathrm{mM}$. [enzyme preparation]: $1 \mathrm{~g} \mathrm{~L}^{-1}$ or $4 \mathrm{~g} \mathrm{~L}^{-1}\left(\mathrm{sc}^{-\mathrm{CO}_{2}}\right)$.

we have shown with an indicator that the salt hydrate pairs used in the present study to control $a_{\mathrm{W}}$ also have acid-base effects on enzymes in nonaqueous solvents [51,52], although when used in the presence of solid-state acid-base buffers, the action of the latter prevails. Thus, the blanks reflect the relative acidity of the salt pairs $\mathrm{Na}_{2} \mathrm{HPO}_{4} \cdot 2 / 0$ and $\mathrm{Na}_{2} \mathrm{HPO}_{4} \cdot 7 / 2$. The pair $\mathrm{Na}_{2} \mathrm{HPO}_{4} \cdot 2 / 0$ led to readings of the indicator that were similar to those obtained in the presence of MOPS buffer [28,34]. The pair $\mathrm{Na}_{2} \mathrm{HPO}_{4} \cdot 7 / 2$ is much more acidic and completely protonated the indicator [51,52]. This also occurred in the presence of GLU buffer [34], and thus the indicator did not discriminate between those two additives.

In sc-ethane and in $n$-hexane, cutinase immobilized on either zeolite $\mathrm{NaY}$ or zeolite $\mathrm{NaA}$ exhibited higher transesterification activity in the presence of acid-base buffers of intermediate basicity, carbonate and GLU buffers with the extreme aqueous $\mathrm{p} K_{\mathrm{a}}$ values generally yielding lower reaction rates. Cutinase is known to perform better for protonation states initially set by a pH of immobilization between 7 and $8.5[39,40] ; 8.5$ was the value selected in this work. In a previous study, we observed that when cutinase was immobilized at $\mathrm{pH} 5$, the enzyme exhibited only marginal activity that increased in the presence of acid-base buffers [17]. This clearly indicates that cutinase has a $\mathrm{pH}$ memory, and also suggests that the aqueous $\mathrm{p} K_{\mathrm{a}}$ of GLU buffer (4.3) most probably does not fully account for its acid-base behavior in nonaqueous media [51], suggesting a higher acidity than what it actually confers. Even so, cutinase is less sensitive to changes in the protonation state of its acidic residues than subtilisin $[35,44,51]$. The failure of the buffers to increase initial reaction rates over the blanks observed here with cutinase may be

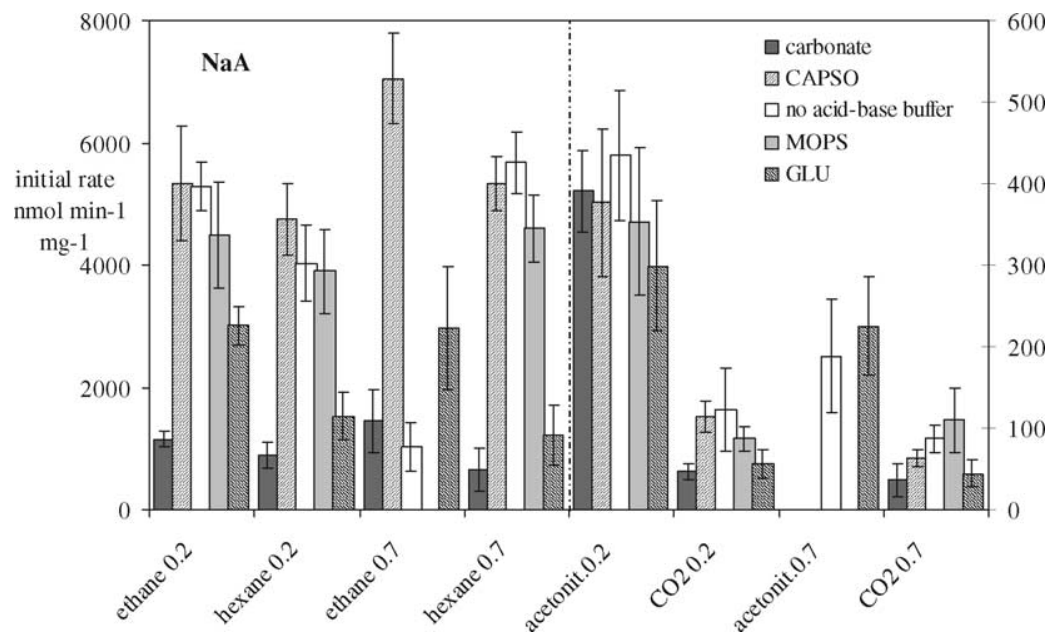

Fig. 2. Effect of solid-state acid-base buffer and aw on the initial rates of transesterification for cutinase immobilized on zeolite NaA in sc-fluids and organic solvents. Left $y$-axis used for sc-ethane and $n$-hexane (data to the left of the dashed line). 
due to the fact that the enzyme was immobilized at an optimum $\mathrm{pH}$, as suggested to explain similar results obtained with immobilized subtilisin [35] and immobilized papain [53]. But as pointed out [35], even in this case the use of the buffers may be advantageous in that the ionization state of the enzyme will be maintained throughout the reaction regardless of the production of acidic or basic species.

The blanks for cutinase at low $a_{\mathrm{W}}$ yielded results very similar to those obtained with MOPS buffer at the same $a_{\mathrm{W}}$, either due to the similar relative acidity of MOPS buffer and the salt pair $\mathrm{Na}_{2} \mathrm{HPO}_{4} \cdot 2 / 0$ or just because of the absence of discrimination generally observed when cutinase was exposed to acid-base buffers with aqueous $\mathrm{p} K_{\mathrm{a}}$ values in the range 9.6-7.2. The situation changed somewhat at high aw. Both MOPS and CAPSO buffers are reported to form hydrates at $a_{\mathrm{W}}$ values higher than 0.23 and 0.53 , respectively [34]. At controlled $a_{\mathrm{W}}$ as ensured here, the formation of those hydrates may lead to a somewhat different $\mathrm{pH}-\mathrm{pNa}$ value than that afforded by the anhydrous forms of the buffer pairs, but this value should not vary among solvents and the buffers might still be expected to function as such. However, no initial rates could be measured at high $a_{\mathrm{W}}$ in acetonitrile with either MOPS or CAPSO buffers. MOPS also did not perform well in sc-ethane at high $a_{\mathrm{W}}$, although it worked well in $n$-hexane at the same $a_{\mathrm{W}}$ and led to higher rates than those obtained with GLU buffer. When using cutinase immobilized on zeolite $\mathrm{NaY}$, the salt pair $\mathrm{Na}_{2} \mathrm{HPO}_{4} \cdot 7 / 2$ alone (blank) led to much higher rates than GLU buffer in both sc-ethane and in $n$-hexane. This may either be due to a lower acidity of the $\mathrm{Na}_{2} \mathrm{HPO}_{4} \cdot 7 / 2$ salt pair compared to GLU, or to a limited capacity of the salt pair for $\mathrm{H}^{+} / \mathrm{Na}^{+}$exchange, as expected of a species that is not a buffer. We note that in addition to the enzyme, the zeolite that accounts for most of the enzyme preparation also participates in all ion-exchange processes. When using cutinase immobilized on zeolite $\mathrm{NaA}$ at high $a_{\mathrm{W}}$, however, the transesterification activity dropped significantly in the blank in sc-ethane. The fact that CAPSO or even GLU buffer were able to increase enzyme activity suggests that the event responsible for the activity drop in the blank was of an acid-base nature. Experiments done in sc-ethane without addition of either acid-base buffer or salt hydrate pairs, where $a_{\mathrm{W}}$ of solvent and enzyme were independently adjusted to 0.7 yielded initial rates of transesterification that were similar (1341 nmol min $\left.{ }^{-1} \mathrm{mg}^{-1}\right)$ to that given in Fig. 2. This confirms that the salt pair $\mathrm{Na}_{2} \mathrm{HPO}_{4} \cdot 7 / 2$ itself is not responsible for the activity drop, as indeed suggested by the results obtained for all the blanks at $a_{\mathrm{W}}=0.7$ except in the specific case of cutinase immobilized on zeolite $\mathrm{NaA}$ in scethane.

Hydrolysis might be the cause for an increase in medium acidity in the blanks. As shown earlier [17], in the presence of the more basic buffers butyric acid precipitates as sodium butyrate and cannot be quantified by routine GC analysis. Here, the quantification of butyric acid was only done in the blanks and in experiments carried out in the presence of MOPS and GLU buffers. The registered levels of hydrolysis were sim-

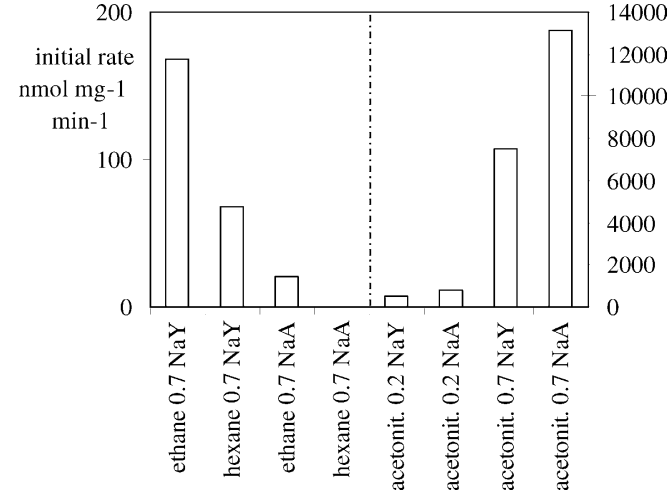

Fig. 3. Initial rates of hydrolysis in sc-fluids and organic solvents. Left $y$-axis used for sc-ethane and $n$-hexane (data to the left of the dashed line).

ilar in sc-ethane and in $n$-hexane, and more pronounced for cutinase immobilized on zeolite NaY (Fig. 3). At low $a_{\mathrm{W}}$, no butyric acid was detected within the experimental error that affects its quantification during the period used to measure rates of transesterification. At high $a_{\mathrm{W}}$, the low levels of acid detected in the medium when using cutinase immobilized on zeolite NaA do not help elucidate the activity drop observed in sc-ethane relative to $n$-hexane.

The results obtained in acetonitrile agree with those previously reported [17]. Unlike in sc-ethane and in $n$-hexane, in acetonitrile increasing $a_{\mathrm{W}}$ was accompanied by a decrease in transesterification activity; also, at low $a_{\mathrm{W}}$ enzyme activity was similar with both supports and hydrolysis was more pronounced when using zeolite NaA. In acetonitrile, the enzyme was clearly insensitive to the acid-base conditions of the medium. These must have changed markedly in the blanks and in the presence of GLU buffer. In fact, it was in acetonitrile that higher rates of hydrolysis were observed. In sc- $\mathrm{CO}_{2}$ enzyme activity was low compared to that measured in the other solvents, a fact quite often encountered when working with hydrolases $[22,24,44,45]$. Possible causes for the deleterious effect of sc- $\mathrm{CO}_{2}$ on enzyme activity have been referred to earlier. The effect of $a_{\mathrm{W}}$ on the rates of transesterification in this solvent was similar to that in sc-ethane and $n$-hexane. Hydrolysis was not detected except at very long reaction times, in agreement with a generally low catalytic activity of cutinase.

In all the solvents, the concentrations of the substrates were low (mole fractions varied from ca. 1E-03 to 3E-03 for the alcohol and ca. 7E-03 to 2E-02 for the ester) and the corresponding activity coefficients should be very close to their limiting values at infinite dilution, $\gamma^{\infty}$. The calculated $\gamma^{\infty}$ for each substrate in the four solvents are given in Table 1. This table provides clear evidence for a direct negative effect of $\mathrm{sc}-\mathrm{CO}_{2}$ on cutinase activity. The data for $\gamma^{\infty}$ shows that in sc- $\mathrm{CO}_{2}$ the desolvation of the substrates from the bulk solvent to the active site was more favorable than in $n$-hexane and in acetonitrile. Higher activities of the substrates suggest higher reaction rates, contrary to what is observed. Thus, sc- $\mathrm{CO}_{2}$ does not have a negative indirect 
Table 1

Calculated infinite dilution activity coefficients for binary mixtures (solute + solvent)

\begin{tabular}{lll}
\hline Solute & Solvent & $\ln \left(\gamma_{\text {solute }}^{\infty}\right)$ \\
\hline 2-Phenyl-1-propanol & sc-Ethane & 3.86 \\
& $n$-Hexane & 2.74 \\
& Acetonitrile & 0.902 \\
& sc-CO 2 & 4.51 \\
Vinyl butyrate & sc-Ethane & 2.46 \\
& $n$-Hexane & 1.11 \\
& Acetonitrile & 0.824 \\
Butyric acid & sc-CO 2 & 1.55 \\
& sc-Ethane & 3.01 \\
& $n$-Hexane & 1.88 \\
\hline
\end{tabular}

solvent effect on cutinase activity mediated by differences in solvation, but rather a marked direct effect. It is in acetonitrile that the substrates are better solvated and less available for reaction. Solvation is also seen to be more effective in $n$-hexane than in sc-ethane, in qualitative agreement with the trend observed in initial rates of transesterification. The presence of the second substrate has no significant effect on $\gamma$ for the other substrate, given the low concentrations involved. Likewise, the impact of $a_{\mathrm{W}}$ on the $\gamma$ values for the two substrates is very small in the solvents that saturate at very low water concentrations. In acetonitrile, however, the increase in $a_{\mathrm{W}}$ to 0.7 is accompanied by a significant dilution of the solvent. A comparison between $\gamma$ values calculated for the quaternary mixtures (Table 2) and the binaries shows a similar trend for the impact of water on $\gamma$ for the substrates, except in the case of the ester substrate in acetonitrile. However, the observed increase in $\gamma$ is small. Therefore, the decrease in the rates of transesterification with increasing $a_{\mathrm{W}}$ that is only observed in acetonitrile should reflect an increasing competition of water against the substrates for binding at the enzyme active site, manifested in higher rates of hydrol-

Table 2

Calculated activity coefficients in quaternary mixtures at $a_{\mathrm{W}}=0.7$

\begin{tabular}{|c|c|c|}
\hline Mixture & Mole fraction & $\ln \gamma$ \\
\hline sc-Ethane & $9.82 \mathrm{E}-01$ & $2.7 \mathrm{E}-03$ \\
\hline Water & $8.10 \mathrm{E}-04$ & 6.8 \\
\hline 2-Phenyl-1-propanol & $2.27 \mathrm{E}-03$ & 3.4 \\
\hline Vinyl butyrate & $1.54 \mathrm{E}-02$ & 2.2 \\
\hline$n$-Hexane & $9.75 \mathrm{E}-01$ & $1.70 \mathrm{E}-03$ \\
\hline Water & $3.97 \mathrm{E}-04$ & 7.47 \\
\hline 2-Phenyl-1-propanol & $3.20 \mathrm{E}-03$ & 2.52 \\
\hline Vinyl butyrate & $2.18 \mathrm{E}-02$ & 1.00 \\
\hline Acetonitrile & $8.05 \mathrm{E}-01$ & $5.45 \mathrm{E}-02$ \\
\hline Water & $1.87 \mathrm{E}-01$ & 1.32 \\
\hline 2-Phenyl-1-propanol & $1.06 \mathrm{E}-03$ & 0.89 \\
\hline Vinyl butyrate & $7.23 \mathrm{E}-03$ & 1.13 \\
\hline $\mathrm{sc}-\mathrm{CO}_{2}$ & $9.83 \mathrm{E}-01$ & $3.10 \mathrm{E}-03$ \\
\hline Water & $2.66 \mathrm{E}-03$ & 5.57 \\
\hline 2-Phenyl-1-propanol & $1.83 \mathrm{E}-03$ & 3.82 \\
\hline Vinyl butyrate & $1.24 \mathrm{E}-02$ & 1.18 \\
\hline
\end{tabular}

[2-Phenyl-1-propanol] $=25 \mathrm{mM}$; [vinyl butyrate] $=170 \mathrm{mM}$. ysis than in the other three solvents. The role of water as a competitive inhibitor is thought to contribute to observed increases in $K_{\mathrm{m}}$ values for substrates, accompanying increases in $a_{\mathrm{W}}[14]$.

Cutinase enantioselectivity towards the alcohol substrate was low ( $E$ values between 1 and 2 ) under all the reaction conditions tested.

\section{Conclusions}

At fixed $a_{\mathrm{W}}$, differences in enzyme activity in various solvents may simply reflect differences in solvation that can be elucidated by calculating the activities of the substrates, as was done here. Interestingly, in sc-ethane and in $n$-hexane the acid-base buffers with the highest and the lowest aqueous $\mathrm{p} K_{\mathrm{a}}$ values yielded initial rates of transesterification of vinyl butyrate by $(R, S)$-2-phenyl-1-propanol that were lower than those obtained with buffers of intermediate $\mathrm{p} K_{\mathrm{a}}$, whereas in acetonitrile cutinase activity simply did not respond to changes in the acid-base conditions of the medium. These differences in the sensitivity of cutinase activity to the acid-base buffers may be related to the differences in polarity of the media. No obvious explanation exists for the comparatively low rate of transesterification obtained in the blank for cutinase immobilized on zeolite $\mathrm{NaA}$, in sc-ethane. The fact that enzyme activity was high in the presence of buffers able to exchange $\mathrm{Na}^{+}$for $\mathrm{H}^{+}$suggests that the butyric acid formed in the blank may be the cause for the activity impairment. The higher diffusivity expected for this by-product in sc-ethane relative to $n$-hexane would seem to contradict the experimental observation. However, the higher $\gamma$ for butyric acid in sc-ethane relative to $n$-hexane (Table 1 ) and thus a higher availability of the acid to the enzyme in that case can at least partly account for the observed behavior, which must also have to do with the type of support. In fact, immobilization of cutinase on either zeolite $\mathrm{NaA}$ or zeolite $\mathrm{NaY}$ is performed under conditions that do not saturate the surface of the support [39]. Also, the yield of immobilization of cutinase on zeolite $\mathrm{NaA}$ is lower than on zeolite $\mathrm{NaY}$. Thus, there will be a comparatively higher number of sites at the surface of zeolite $\mathrm{NaA}$ available for the binding of solutes. Given that zeolite $\mathrm{NaA}$ is the more hydrophilic of the two, butyric acid should have a higher affinity for the sites available at the surface of this zeolite than for those available on zeolite NaY.

\section{Acknowledgments}

This work has been supported by Fundação para a Ciência e Tecnologia (FCT, Portugal) through the contracts PRAXIS/P/BIO/14314/1998 and POCTI/35429/QUI/2000 and the grant PRAXIS XXI/BD/21615/99 (S. Garcia), and by FEDER.We thank Ricardo Baptista for help in the production of cutinase. 


\section{References}

[1] J.M. DeSimone, Practical approaches to green solvents, Science 297 (2002) 799-803.

[2] M. Poliakoff, J.M. Fitzpatrick, T.R. Farren, P.T. Anastas, Green chemistry: science and politics of change, Science 297 (2002) 807-810.

[3] A.J. Mesiano, E.J. Beckman, A.J. Russell, Supercritical biocatalysis, Chem. Rev. 99 (1999) 623-633.

[4] A.M. Klibanov, Improving enzymes by using them in organic solvents, Nature 409 (2001) 241-246.

[5] S.H. Krishna, Developments and trends in enzyme catalysis in nonconventional media, Biotechnol. Adv. 20 (2002) 239-266.

[6] P.A. Fitzpatrick, A.C.U. Steinmetz, D. Ringe, A.M. Klibanov, Enzyme crystal structure in a neat organic solvent, Proc. Natl. Acad. Sci. USA 90 (1993) 8653-8657.

[7] N.H. Yennawar, H.P. Yennawar, G.K. Farber, X-ray crystal structure of $\gamma$-chymotrypsin in hexane, Biochemistry 33 (1994) 7326-7337.

[8] J.L. Schmitke, L.J. Stern, A.M. Klibanov, Crystal Structure of subtilisin Carlsberg in anhydrous dioxane and its comparison with those in water and acetonitrile, Proc. Natl. Acad. Sci. USA 94 (1997) 4250-4255.

[9] K. Griebenow, A.M. Klibanvov, On protein denaturation in aqueousorganic mixtures but not in pure organic solvents, J. Am. Chem. Soc. 47 (1996) 11695-11700.

[10] J.A. Rupley, E. Gratton, G. Careri, Water and globular proteins, Trends Biochem. Sci. 8 (1983) 18-22.

[11] J.A. Rupley, G. Careri, Protein hydration and function, Adv. Protein Chem. 41 (1991) 37-172.

[12] G. Bell, P.J. Halling, B.D. Moore, J. Partridge, D.G. Rees, Biocatalyst behaviour in low-water systems, Trends Biotechnol. 13 (1995) 468-473.

[13] P.J. Halling, Thermodynamic predictions for biocatalysis in nonconventional media:theory, tests and recommendations for experimental design and analysis, Enzyme Microb. Technol. 16 (1994) 178-206.

[14] G. Bell, A.E.M. Janssen, P.J. Halling, Water activity fails to predict critical hydration level for enzyme activity in polar organic solvents: interconversion of water concentrations and activities, Enzyme Microb. Technol. 20 (1997) 471-477.

[15] J.H. McMinn, M.J. Sowa, S.B. Charnick, M.E. Paulaitis, The hydration of proteins in nearly anhydrous organic solvent suspensions, Biopolymers 33 (1993) 1213-1224.

[16] R.H. Valivety, P.J. Halling, A.D. Peilow, A.R. Macrae, Relationship between water activity and catalytic activity of lipases in organic media. Effects of supports, loading and enzyme preparation, Eur J. Biochem. 222 (1994) 461-466.

[17] P. Vidinha, N. Harper, N.M. Micaelo, N.M.T. Lourenço, M.D.R. Gomes da Silva, J.M.S. Cabral, C.A.M. Afonso, C.M. Soares, S. Barreiros, Effect of immobilization support, water activity and enzyme ionization state on cutinase activity and enantioselectivity in organic media, Biotechnol. Bioeng. 85 (2004) 442-449.

[18] R. Affleck, Z.F. Xu, V. Suzawa, K. Focht, D.S. Clark, J.S. Dordick, Enzymatic catalysis and dynamics in low-water environments, Proc. Natl. Acad. Sci. USA 89 (1992) 1100-1104.

[19] J. Partridge, P.R. Dennison, B.D. Moore, P.J. Halling, Activity and mobility of subtilisin in low water organic media: hydration is more important than solvent dielectric, Biochim. Biophys. Acta 1386 (1998) 79-89.

[20] S. Toba, D.S. Hartsough, K.M. Merz, Solvation and dynamics of chymotrypsin in hexane, J. Am. Chem. Soc. 118 (1996) 6490-6498.

[21] F. Vázquez Lima, D.L. Pyle, J.A. Asenjo, Factors affecting the esterification of lauric acid using an immobilized biocatalyst: Enzyme characterization and studies in a well-mixed reactor, Biotechnol. Bioeng. 46 (1995) 69-97.

[22] I. Borges de Carvalho, T. Corrêa de Sampaio, S. Barreiros, Solvent effects on the catalytic activity of subtilisin suspended in compressed gases, Biotechnol. Bioeng. 49 (1996) 399-404.
[23] T. Corrêa de Sampaio, R.B. Melo, T.F. Moura, S. Michel, S. Barreiros, Solvent effects on the catalytic activity of subtilisin suspended in organic solvents, Biotechol. Bioeng. 50 (1996) 257-264.

[24] N. Fontes, E. Nogueiro, A.M. Elvas, T. Corrêa de Sampaio, S. Barreiros, Effect of pressure on the catalytic activity of subtilisin carlsberg suspended in compressed gases, Biochim. Biophys. Acta 1383 (1998) 165-174.

[25] G. Sandoval, J.S. Condoret, P. Monsan, A. Marty, Esterification by immobilized lipase in solvent-free media: kinetic and thermodynamic arguments, Biotechnol. Bioeng. 78 (2002) 313-320.

[26] J. Kim, D.S. Clark, J.S. Dordick, Intrinsic effects of solvent polarity on enzymic activation energies, Biotechnol. Bioeng. 67 (2000) $112-116$.

[27] J.L. Schmitke, L.J. Stern, A.M. Klibanov, Organic solvent binding to crystalline subtilisin in mostly aqueous media and in the neat solvents, Biochem. Biophys. Res. Commun. 248 (1998) 273277.

[28] N. Harper, S. Barreiros, Enhancement of enzyme activity in supercritical carbon dioxide via changes in acid-base conditions, Biotechnol. Prog. 18 (2002) 1451-1454.

[29] S.V. Kamat, E.J. Beckman, A.J. Russell, Enzyme activity in supercritical fluids, Crit. Rev. Biotechnol. 15 (1995) 41-71.

[30] P.J. Halling, Biocatalysis in low-water media: understanding effects of reaction conditions, Curr. Opin. Chem. Biol. 4 (2000) 74-80.

[31] A. Zaks, A.M. Klinanov, Enzyme-catalyzed processes in organic solvents, Proc. Natl Acad. Sci. USA 82 (1985) 3192-3196.

[32] K. Xu, A.M. Klibanov, $\mathrm{pH}$ control of the catalytic activity of crosslinked enzyme crystals in organic solvents, J. Am. Chem. Soc. 118 (1996) 9815-9819.

[33] N. Fontes, P.J. Halling, S. Barreiros, Control of enzyme ionization state in supercritical ethane by sodium/proton solid-state acid-base buffers, Enzyme Microb. Technol. 33 (2003) 938-941.

[34] N. Harper, M. Dolman, B.D. Moore, P.J. Halling, Acid-base control for biocatalysis in organic media: new solid-state proton/cation buffers and an indicator, Chem. Eur. J. 6 (2000) 1923-1929.

[35] J. Partridge, P.J. Halling, B.D. Moore, Solid-state proton/sodium buffers: 'chemical $\mathrm{pH}$ stats' for biocatalysts in organic solvents, J. Chem. Soc., Perkin Trans. 2 (2000) 465-471.

[36] E. Zacharis, B.D. Moore, P.J. Halling, Control of enzyme activity in organic media by solid-state acid-base buffers, J. Am. Chem. Soc. 119 (1997) 12396-12397.

[37] C.M.L. Carvalho, M.R. Aires-Barros, J.M.S. Cabral, Cutinase: from molecular level to bioprocess development, Biotechnol. Bioeng. 66 (1999) 17-34.

[38] M. Lauwereys, P. de Geus, J. de Meutter, P. Stanssens, G. Matthyssens, Cloning, expression and characterisation of cutinase, a fungal lipolytic enzyme, in: L. Alberghina, R.D. Schmid, R. Verger (Eds.), Lipases: Structure, Mechanism and Genetic Engineering, VCH, New York, 1990, pp. 243-251.

[39] A.P.V. Gonçalves, J.M. Madeira Lopes, F. Lemos, F. Ramôa Ribeiro, D.M.F. Prazeres, J.M.S. Cabral, M.R. Aires-Barros, Zeolites as suppports for enzymatic hydrolysis reactions: comparative study of several zeolites, J. Mol. Catalysis B: Enzym. 1 (1996) 53-60.

[40] F.N. Serralha, J.M. Lopes, F. Lemos, D.M.F. Prazeres, M.R. AiresBarros, J.M.S. Cabral, F.R. Ribeiro, Zeolites as supports for an enzymatic alcoholysis reaction, J. Mol. Catal. B: Enzym. 4 (1998) 303-311.

[41] O.H. Lowry, N.J. Rosenbrough, L. Farr, R. Randal, Protein measurement with the Folin phenol reagent, J. Biol. Chem. 193 (1951) 265-275.

[42] N. Fontes, M.C. Almeida, S. Barreiros, Biotransformations in supercritical fluids, in: E.N. Vulfson, P.J. Halling, H.L. Holland (Eds.), Enzymes in Nonaqueous Solvents: Methods and Protocols, Methods in Biotechnology, Vol. 15, Humana Press, New Jersey, 2001, pp. $565-573$.

[43] P.J. Halling, Salt hydrates for water activity control with biocatalysts in organic media, Biotechnol. Tech. 6 (1992) 271-276. 
[44] N. Fontes, J. Partridge, P.J. Halling, S. Barreiros, Zeolite molecular sieves have dramatic acid-base effects on enzymes in nonaqueous media, Biotechnol. Bioeng. 77 (2002) 296-305.

[45] N. Fontes, M.C. Almeida, S. Garcia, C. Peres, J. Partridge, P.J. Halling, S. Barreiros, Supercritical fluids are superior media for catalysis by cross-linked enzyme microcrystals of subtilisin Carlsberg, Biotechnol. Prog. 17 (2001) 355-358.

[46] L. Greenspan, Humidity fixed points of binary saturated aqueous solutions, J. Res. Nat. Bur. Stand. - A. Phys. Chem. 81A (1977) 89-96.

[47] A.J.J. Straathof, J.A. Jongejan, The enantiomeric ratio: origin, determination and prediction, Enzyme Microb. Technol. 21 (1997) 559-571.

[48] B.L. Larsen, P. Rasmussen, A. Fredenslund, A modified UNIFAC group-contribution model for prediction of phase equilibria and heat of mixing, Ind. Eng. Chem. Res. 26 (1987) 2274-2286.
[49] S. Dahl, A. Fredenslund, P. Rasmussen, The MHV2 model: A UNIFAC-based equation of state model for prediction of gas solubility and vapor liquid equilibria at low and high pressures, Ind. Eng. Chem. Res. 30 (1991) 1936-1945.

[50] S. Dahl, M.L. Michelsen, High pressure vapor-liquid equilibrium with a UNIFAC based equation of state, Fluid Phase Equilib. 36 (1990) 1829-1836.

[51] N. Fontes, N. Harper, P.J. Halling, S. Barreiros, Salt hydrates for in-situ water activity control have acid-base effects on enzymes in nonaqueous media, Biotechnol. Bioeng. 82 (2003) 802 808.

[52] Peres et al., to be published.

[53] T. Theppakorn, P. Kanasawud, P.J. Halling, Effect of solid-state buffers on the catalytic activity of papain in low-water media, Enzyme Microb. Technol. 32 (2003) 828-836 